TEI

OURNAL OF THE Journal of the Text Encoding Initiative

Issue 12 | July 2019 - May 2020

Selected Papers from the 2017 TEI Conference

\title{
The Switchover: Teaching and Learning the Text Encoding Initiative in Spanish
}

Susanna Allés-Torrent and Gimena del Rio Riande

\section{OpenEdition}

\section{Journals}

Electronic version

URL: http://journals.openedition.org/jtei/2994

DOI: 10.4000/jtei.2994

ISSN: 2162-5603

Publisher

TEl Consortium

\section{Electronic reference}

Susanna Allés-Torrent and Gimena del Rio Riande, «The Switchover: Teaching and Learning the Text Encoding Initiative in Spanish », Journal of the Text Encoding Initiative [Online], Issue 12 I July 2019 -

May 2020, Online since 12 May 2020, connection on 25 June 2020. URL : http://

journals.openedition.org/jtei/2994; DOI : https://doi.org/10.4000/jtei.2994

For this publication a Creative Commons Attribution 4.0 International license has been granted by the author(s) who retain full copyright. 


\title{
The Switchover: Teaching and Learning the Text Encoding Initiative in Spanish
}

\author{
Susanna Allés-Torrent and Gimena del Rio Riande
}

\section{ABSTRACT}

This article analyses the current situation of the Text Encoding Initiative (TEI) in a Spanishspeaking digital humanities (DH) education and research context. It also examines the challenges faced when teaching TEI in Spanish and takes into consideration two main issues: the still not well-defined DH curriculum in many Spanish-speaking countries and the different pedagogical approaches to the TEI depending on the learning context: face-to-face instruction, distance education, and the Foreign Language Classroom. It aims as well to raise awareness about the lack of basic pedagogical materials-tutorials or guidelines-devoted to TEI in Spanish, an obstacle that has hindered the growth of a TEI community of practice from Spain and Latin America. It also 
offers some strategies and new resources that could benefit the outreach and adoption of the TEI inside and outside the Spanish-speaking DH community, while facilitating a new TEI curriculum in a higher education context.

\section{INDEX}

Keywords: teaching resources, Spanish, Latin America, Spain, humanidades digitales, diversity, distant learning

\section{Introduction}

Digital humanities (DH) tools, methods, and resources are becoming increasingly common in the higher education context. The Text Encoding Initiative (TEI) standard for encoding and publishing digital texts is now part of the DH core undergraduate and graduate curriculum. ${ }^{1}$ To be more precise, this statement is true for the anglophone world, which quickly took advantage of the TEI standards for creating searchable, enriched, interoperable, and well preserved texts and databases. However, the situation is significantly different in Spanish-speaking countries.

2 The leading role of the anglophone DH community, as well as the hegemonic role of English for global scientific communication, ${ }^{2}$ have created a field where multilingual resources are still difficult to find. Yet, in the last five years, it may be observed that DH is in the midst of a significant global turn where many aspects related to diversity and equity have come into question, therefore highlighting the barriers to the participation of a globalized population and other equity-seeking groups within the field (O'Donnell 2012; Galina 2013; Fiormonte 2014; O'Donnell et al. 2016a; O'Donnell et al. 2016b; Fiormonte and del Rio Riande 2017).

3 DH has become not only a multidisciplinary field but also a more globally connected discipline, facing human challenges such as multilingualism, equity, and diversity. Consequently, the ability to communicate across cultural boundaries has gained increasing prominence in the field (del Rio Riande 2015a, 2015b, 2016a, 2016b). This situation can be applied to the TEI and its global community of practice. In fact, one of the last TEI Conferences, held in Japan in 
2018, was specifically titled "TEI as a Global Language," highlighting the potential of TEI as a global (meta)language applied to Humanities and Social Science texts written in many different languages. ${ }^{3}$

4 Throughout this work, the authors-who are both Spanish speakers, but working in two different academic contexts, one in North America and one in South America-will examine what it means to teach and learn the TEI in a Spanish-speaking class situation. This article will therefore focus on three main points: a general overview of the interest in adopting the TEI as a standard to represent a variety of humanities texts; the challenges of teaching TEI in Spanish within an ill-defined and emerging DH curricular context, as well as in different pedagogical environments such as face-toface instruction and distance education in a native-speaking context, and the Foreign Language Classroom; and an outline of the obstacles and challenges we have faced after almost seven years of teaching TEI in Spanish, together with a set of strategies and resources for improving the overall situation.

\section{The Humanidades Digitales Curriculum and the $\mathrm{TEI}^{4}$}

5 Despite the early interest in the intersection between humanities and technology (Marcos Marín 1986; Irizarry 1997; del Rio Riande 2015a, 2016a), DH only recently became a wider and recognizable field known as "humanidades digitales" in the Spanish-speaking world. Since 2012 several Latin American and Spanish DH associations, such as RedHD in Mexico, ${ }^{5}$ AHDig: Associação das Humanidades Digitais in Brazil, ${ }^{6}$ Sociedad Internacional de Humanidades Digitales Hispánicas (HDH) in Spain, the Associació d'Humanitats Digitals Catalanes in Catalonia, ${ }^{8}$ and the Asociación Argentina de Humanidades Digitales (AAHD), founded in 2013 during THATCamp Buenos Aires, started populating the global DH landscape. ${ }^{10}$ More recently, the Red Colombiana de Humanidades Digitales (RedCo $)^{11}$ in Colombia came into play, as well as more informal initiatives in Perú and Uruguay, ${ }^{12}$ and others with a regional Latin American scope, such as Latamhd. ${ }^{13}$

6 Thus, during the last decade, the Spanish-speaking DH higher education curriculum experienced a sudden-although unstable-growth. In Spain, as early as 2006, the Escuela Superior de Ingeniería Informática at the Universidad de Castilla-La Mancha opened a short-lived MA in Digital Humanities, but only since 2016 have other Spanish universities, such as the Universidad de Salamanca, with its MA in Textual Heritage and Digital Humanities, the Universidad Pablo Olavide 
(Seville) ${ }_{1}^{14}$ with the MA in History and Digital Humanities, the Universitat Autònoma de Barcelona ${ }^{15}$ and Universitat de Barcelona ${ }^{16}$ started incorporating DH in their postgraduate curriculum. ${ }^{17}$ Also, postgraduate courses that focus on digital literature, such as the ones offered at the Universidad Complutense de Madrid by the Research Group LEETHI, joined the formal DH training landscape in Spain. ${ }^{18}$ In the realms of distance education, the Laboratorio de Innovación en Humanidades Digitales (LINHD), at the Universidad Nacional de Educación a Distancia (UNED), has been since 2014 the only institution with a continuous academic offering of DH courses in which professors from Spain and Latin America participate (González-Blanco et al. 2017a) ${ }^{19}$ In 2019, LINHD merged its different DH semester certificates-the Experto en Humanidades Digitales, Experto en Edición Digital Académica, Experto en Programación con R-into a single university-specific MA, the "Máster Universitario en Humanidades Digitales." ${ }^{20}$ Another online university, La Universidad en Internet--Universidad Internacional de La Rioja (UNIR) has proposed a new MA in Digital Humanities that will include a module in digital editing. ${ }^{21}$ On the other side of the Atlantic Ocean, in Latin America, DH instruction has been mostly represented by the MA degree of the Universidad de Los Andes (Colombia) ${ }^{22}$ and the one at the Universidad del Claustro de Sor Juana (México). ${ }^{23}$ However, there are many informal DH initiatives worth highlighting, such as the Seminario HD in México, that is part of the activities of the RedHD at UNAM (Universidad Nacional Autónoma de México, Facultad de Filosofía y Letras) ${ }^{24}$ (Priani Saisó 2007), and the many DH events organized between the Asociación Argentina de Humanidades Digitales (AAHD) and Humanidades Digitales CAICYT Lab (CONICET) ${ }^{25}$ that have together been offering workshops, courses, and conferences.

7 Despite this current positive context, the last ten years show a slow uptake in the use of the TEI as the standard for encoding and exchanging humanities data in most of the Spanish-speaking countries, being mostly limited to DH projects from Spain. In broad terms, the general feeling is a lack of awareness and mastery when compared, for instance, to anglophone Digital Scholarly Editions (DSE) projects, as well as a lack of communication with those research groups; TEI is not well known and its use is limited, especially if contrasted with other non-anglophone countries such as France or Germany, where it was adopted early in Humanities Computing projects.

$8 \quad$ Nonetheless, we can trace an early interest in the TEI that goes back at least to the early 1990s and 2000s (Faulhaber 1994; Marcos Marín 1994; Morrás 2003), though it is in the next decade when the TEI seems to gain more traction with one-day workshops such as "Introducción a los lenguajes 
de marcado de texto: XML y TEI" (Alejandro Bia), ${ }^{26}$ or as part of events (the workshop taught by Paul Spence at the First Conference of the HDH association in 2013 at the Universidade da Coruña, España), and also other very specific ones like "XML-TEI for Ancient and Medieval Lexicographical Works," held at the Institució Milà i Fontanals-CSIC in Barcelona that same year. ${ }^{27}$ When it comes to TEI teaching, LINHD is currently, as mentioned, the only institution offering TEI training, devoting two three-month modules to text encoding and the TEI in its MA in DH. Moreover, since 2014, LINHD has been organizing DH summer schools in which TEI has always been part of the agenda.

9 In contrast, in Latin America, we find TEI mostly confined to a few projects and informal education. ${ }^{28}$ Since 2012 many TEI workshops have been held in México, at the RedHD conferences, and at the TEC (Monterrey) by North American experts. Further south, in Argentina, we find oneday TEI workshops on the TEI since 2013, initially at the THATCamp Buenos Aires,$^{29}$ and then at the First National Conference of the AAHD (2014), ${ }^{30}$ as well as at its Second International Conference (2016), and at Citep UBA (2018) ${ }^{31}$ However, we can also trace postgraduate courses devoted to TEI at the Universidad de Buenos Aires ${ }^{32}$ and the Universidad Nacional de Mar del Plata, as well as a onemonth summer school on TEI at Universidad de La Plata (2015) ${ }^{33}$ Finally, two-day TEI workshops were also taught at Pontificia Universidad Católica in Chile in $2017,{ }^{34}$ and at different events in Cuba in 2017 and 2018..$^{35}$ Scholarly literature about the TEI finds a certain continuity in Spain after the 2000s (Lucía Megías 2008). Other work published subsequently offers general overviews that concentrate only on the Spanish situation, with no reference to Latin American experiences (Spence 2014; Spence and González-Blanco 2014; Allés-Torrent 2017). Nonetheless, in the last few years a growing number of publications dealing with TEI and its application in Spain and Latin American projects can be found (Faulhaber 1994; Fradejas 2009; Revenga 2014; Allés-Torrent 2015; González-Blanco et al. 2014, 2016; del Rio Riande and Zubillaga 2015; Rojas Castro 2017; Priani Saisó 2017; and McCarl 2018, among many others).

11 It is interesting to note that the landscape of DH projects and DSE related to Hispanic texts shows some very specific features. Gathering information from two existing catalogues ${ }^{36}$ we can assert that DSEs are a common practice among scholars interested in Medieval Hispanic texts (such as Cantar de Mío (id) ${ }^{37}$ and Early Modern Literature-the so-called Golden Age period-but TEI is not always used as a standard in them. In this group we find editions of classical plays such as Miguel de 
Cervantes' La Entretenida or Lope de Vega's La Dama Boba, and others regarding Don Quixote through well-funded projects (Allés-Torrent 2017). Early Mexican manuscripts are minimally represented by El sitio de Guaman Poma, or the Codice Mendoza. ${ }^{38}$ Other initiatives deal with the nineteenth and twentieth centuries, such as "En el ojo del huracán” Cartas de Yltramar a España, 1823-Edición Digital, The Pérez Galdós Edition Project, the Manuscrito digital de Juan Goytisolo or Obras Completas de José Luis Romero, ${ }^{39}$ among the ones using TEI. We emphasize that many of them were carried out in nonhispanic institutions (Cantar de Mio Cid, El sitio de Guaman Poma, Manuscrito digital de Juan Goytisolo), and that others, like the Quijote Interactivo, a pioneering website hosted by the Biblioteca Nacional de España, were built with proprietary and quite obsolete technologies such as Adobe Flash Player, or not using any textual markup, as in the case of the Códice Mendoza, funded by the INAH in Mexico, which seems focused on the spatial representation of the mesoamerican manuscript images.

Even when using the TEI, these editions do not always declare their use thereof, and only a few of them, such as the Biblioteca Digital del Pensamiento Novohispano, present clear documentation on their encoding practice. ${ }^{40}$ TEI was used in the two most important Spanish projects in Digital Libraries in the early 2000s: the Biblioteca Virtual Miguel de Cervantes and Corpus Diacrónico del Español (CORDE). Although these projects were pioneers in Spain and they undertook the creation of corpora using standards, such as the TEI, they left almost no documentation about their practice (Bia and Pedreño, 2001).

\section{Pedagogy and TEI in Spanish}

\subsection{What Do We Want to Teach or ... What Can We Teach?}

The growing global interest in DH has resulted in an increasing number of courses, modules, certificates, and even degrees covering a broad range of topics at the intersection of Humanities and Information and Communication Technology (ICT) methods. However, despite the numerous efforts to train students and researchers formally in the wide-ranging field of $\mathrm{DH}$, "scholarship in this area has tended to focus on research methods, theories, and results rather than critical pedagogy and the actual practice of teaching" (Hirsch 2012). The publication of key resources, such as Digital Pedagogy in the Humanities by MLA Commons, filled this critical gap. ${ }^{41}$ One of the most important unanswered questions in our field remains whether we can-in theory and practice- 
pursue not only new ways of thinking about the humanities but also new ways of teaching and interacting with students mediated by digital tools. To that end, open educational resources, tools, and training materials play a primary role. Many academic publications have called for formal education in $\mathrm{DH}$, including the special edition of the DH Quarterly on Undergraduate Education ${ }^{42}$ and Battershill and Ross (2017), about DH in the classroom. Pedagogy has also been at the forefront of some key events, such as the annual Digital Humanities Summer Institute in Victoria beginning in 2007, and in the re-establishment of the Education SIG of the Text Encoding Initiative at the TEI members' meeting in November 2017.43 Moreover, the mini-conferences on pedagogy now held regularly during the ADHO conference have envisioned the establishment of an ADHO SIG on Digital Pedagogy. Other initiatives support the curation of teaching materials, such as the well-funded platform \#dariahTeach under the mission of gathering "open-source, high quality, multilingual $[\mathrm{DH}]$ teaching materials for the digital arts and humanities." ${ }^{\prime 4}$ All in all, these initiatives reflect more than ever how weas instructors-want to communicate and interact with our students. At the same time, they underscore the challenge of what we can teach, depending on the different educational contexts. Inside the Spanish-speaking community, many debates on the anglo-US centrism, as well as on the heterogeneity of approaches on topics such as how to understand $\mathrm{DH}$, what to teach, and, essentially, whether digital humanities equals humanidades digitales, are taking place (del Rio Riande 2015a, 2016a, 2016b). What seems obvious is that all global practices are born out of local circumstances that shape the ways through which we navigate the different contexts, locally and globally. In each country, and even at the lower levels of regions and institutions, we can find a different academic tradition and a different methodological approach to their cultural, literary, and artistic heritage. At this point, two key elements come into play: on the one hand, the different academic dynamics that may hinder the diversification of programs and approaches, and on the other hand, the fact that the Spanish-speaking community has approached the TEI with a specific interest in the creation of DSE and digital corpora. Although we do not intend to deal with editorial theory in this paper, we think that, in addition to the problem of language, one of the main challenges we should consider in order to adopt and adapt the use of the TEI is the reconceptualization of the Anglo-American and British textual critical traditions that generally inform the TEI. The so-called crítica textual hispánica (hispanic textual criticism) holds a central 
position in Spanish philological studies, but-with some exceptions-it is completely unknown in Latin America, where scholars have separated the concept of the literary text from philology or textual criticism (Rodríguez Temperley 2008). Thus, as an academic discipline, philology is almost nonexistent in Latin America, where only Classical or Medieval Studies make reference to it. Approaches to texts are, consequently, very different in Hispanic contexts than in anglophone contexts. Teaching TEI in these settings requires different digital practices that are adapted to these different cultural traditions in the classroom and in research projects.

17 This humanidades digitales context consequently demands, following Hirsch (2012), not only the emergence of research methods and theories, but also a critical pedagogical approach and a reframing of teaching practice. In other words, we should meditate on how we should approach the teaching of the TEI, under a set of particular cultural and linguistic circumstances ${ }^{45}$ in order to make it worth learning, to overcome the steep learning curve, and to convincingly embrace it from a broader cultural and humanistic perspective. As instructors, we should be able to readjust general and global goals to local or national praxis, melding tradition with new digital practices. Consequently, among the many tasks that we should undertake to facilitate the learning and thus the adoption of the TEI in our different contexts, we should approach text encoding practice not only in our own language but from our own cultural tradition; then, we should adapt practices and guidelines to our own work and draft documentation in order to facilitate learning; we should teach TEI and other text encoding methods, applying truly digital processes and delivering digital outcomes; and finally, we should be aware of job opportunities requesting DH expertise inside and outside academia, and hence prepare students for those markets. From the student's perspective, and in the case of TEI learning, we think that instruction should be rooted in multiple competencies and goals, some of which must target global trends towards best practices, while others must be adapted to local ones. In broad terms and from a technical perspective, students should master the fundamentals of XML standards and related languages; understand the mechanisms of TEI; navigate and use the TEI Guidelines; be aware of the best practices of the TEI community; model the markup of different textual types by themselves; create and customize schemas; be able to draft technical documentation about encoding and digital projects; be acquainted with the existing tools for using, exploiting, and preserving TEI documents; and practice collaborative work. But targeting these technical goals will not be enough if we do 
not also point towards a bigger picture and to real-case examples and scenarios where TEI can be useful, such as in cultural institutions, libraries, and publishing houses. ${ }^{46}$ Moreover, this change should be accompanied by a general discourse on text technologies, by the many dimensions that a text can adopt, and by a holistic understanding of how digital methods can improve the quality of students' work and skills for the job market.

\subsection{Different Pedagogical Contexts}

19 The reflection on what we teach or what we can teach should take into consideration where the teaching happens too. There are different pedagogical and linguistic contexts in which TEI can be taught. From our teaching experience, we can give account of at least three different scenarios where we have worked with students on the use of TEI. Each of them required different pedagogical approaches: first, the traditional face-to-face classroom teaching using a common native language; second, distance education also using Spanish as a native language; and third, the Foreign Language Classroom where learning TEI is performed using a second language.

\subsubsection{Teaching TEI to Spanish Speakers in a Face-to-Face Classroom}

Face-to-face teaching, also known as frontal teaching, chalk-and-talk, and teacher-centered instruction (Dee 2014), is the most traditional and unexceptional learning situation, as well as the one that favors a more active-learning approach. However, we find this approach adopted only for workshops, due to the fact that TEI is not yet offered as part of a regular course at the undergraduate or graduate level at universities. As expected, among the general benefits of this modality are the possibility of doing hands-on practice in the classroom and correcting the students' work in class in a process that can involve professors, while also exchanging materials among students and doing peer-revision. In addition, it creates an environment that facilitates a situated learning experience, as proposed by Lave and Wenger (1991), who argue that the learning process should be in service of the activity, context, and culture in which it occurs. Social interaction is one of the most important components in this approach, as it empowers the construction of, and feeling of belonging to, a community of practice. As TEI is, precisely, a community of practice, this seems to be a perfect environment for students to use a hands-on approach and feel more involved. These advantages are obviously reinforced by the use of the students' native language and also the work on texts written in their native language. of course, 
the more familiar students are with them, the more likely they are to understand what markup is appropriate or useful, though it involves the use of another artificial language (that sometimes is not completely familiar). Nevertheless, because this kind of training is represented mostly by two or four-hour workshops, as part of conferences or specific events, instead of a full semester class, there is not enough time to deal with the full stack of technologies involved in the process of TEI publication. ${ }^{47}$

\subsubsection{Teaching TEI to Spanish Speakers in a Distance Classroom}

Distance education is currently a leading force in the academic and professional world: online universities, courses, and MOOCs have reconfigured the way we teach and learn. As we stated previously, we have been involved with LINHD's distance "MA in DH" courses since 2015 and with its summer schools since 2014. We have also taught a distance summer course devoted to TEI and DSE at Universidad de La Plata (Argentina). ${ }^{48}$

Our TEI distance courses ${ }^{49}$ have attracted the attention of adult students with an academic background, a small amount of time available (due to work or family reasons), and an engagement in continuous educational training. The main advantage of this kind of course is the permanent access to platforms and course materials, which confers a greater flexibility for this audience in terms of "the learner's own time" and of their "familiarities and motivation" (Dee, Foradi, Šarić 2016: 20, Mahony and Pierazzo 2012: 224). However, in this kind of environment, both teachers and students lose immediacy, since all communication has to be done through forums and emails. While distance courses are able to attract a larger and more heterogeneous student body, they hinder the instructor's ability to interact with individual students and their motivations and needs (Terras, Van Den Branden \& Vanhoutte 2009: 299).

In this kind of environment, teaching TEI or other specific technologies faces one major problem: learning a notably hands-on field only through a distance method and by virtual learning. Thus, corrections and feedback on results are sometimes difficult to explain, highlight, and follow, so it is hard to turn these moments into an active learning experience. We believe that improvements to distance Spanish TEI training should aim to address two needs: the need for completeness and explicitness of the materials in an online educational space; and the need to offer materials in Spanish, in a form neutral enough to respond to different nations that share a common language (Spain, Latin America). In the case of the distance courses in which we have been involved, the 
emphasis was placed on creating our own learning materials in Spanish: some were translations of parts of the TEI website content; some were newly-created content adapted to projects and examples of Spanish text encoding; and others required the creation of interactive quizzes through which students could test their learning. We have also worked in building a specific and relevant Spanish corpus for our students.

\subsubsection{Teaching TEl to Non-Spanish Speakers in Spanish}

24 There is a third and perhaps more complex scenario where we teach TEI: the foreign language classroom..$^{50}$ In the case of the North American academy, for example, many departments of Modern Languages and Literatures are hiring DH faculty, who are bringing technologies, methods, and concepts to apply to it. This policy is not only extending the importance of Spanish as a second language at university, but giving visibility to the Hispanic community, the largest linguistic minority in the United States, where some impressive digital initiatives and projects are emerging, such as the Relaciones Geográficas ${ }^{51}$ (providing data for 71 towns in New Spain) or the first US Digital Humanities Center for Latina/o Studies at the University of Houston. ${ }^{52}$

Needless to say, in these latter cases we work with advanced undergraduate learners who have mastered a second language, although sometimes not comprehensively. In an ideal situation, we would work with Spanish texts to be encoded as well as teaching materials also in the target language. The reality, however, is that we encounter great challenges, such as the lack of materials adapted to different oral and written language levels. Students go through a twofold process: they learn new DH concepts while they improve their language skills. Thus, they need additional materials, such as bilingual glossaries, which must be extremely detailed and self-explanatory. As a general conclusion, we can say that learning an encoding practice and publishing with TEI can be a way for students to engage with literature (Cummings 2007; Baldwin 2013); and it can also entail a certain type of hermeneutics and appropriation of the texts (Burnard 2001), while the student is using the second language (in this case, Spanish) to communicate in class and learn. 


\section{The Dearth of TEl Teaching Resources in Spanish} dearth of resources for TEI written in Spanish. This problem affects instructors, students, and the TEI and DH global community in general, and it emerges in many different ways. ${ }^{53}$ Without the aim of being exhaustive, we see the most prominent obstacles as follows.

27 Spanish. The very first translation by Verónica Zumárraga and Marcela Tabanera, the Manual para la codificación e intercambio de textos informatizados. Normas de la Text Encoding Initiative, translated only version 1.01 of the Guidelines (Marcos Marín, 1986: 89). This translation project was later taken up by Alejandro Bia and Carmen Arronis Llopis, and their unfinished work was published on the TEI website.$^{54} \mathrm{~A}$ complete and authoritative translation of TEI documentation (elements, attributes, and so forth) remains urgent. This challenge is now being addressed by the newly established TEI Working Group on Internationalization (I18n). ${ }^{55}$

Although this is slowly changing, the TEI website itself does not offer even a landing page in other languages, and all descriptive prose is in English. This monolingual website thus becomes a barrier to novice users from other linguistic areas.

There are still some debates as to how to accomplish internationalization, such as the translation of tags. In 2005, Sebastian Rahtz said "we need to make sure that the TEI and its Guidelines are internationalized and localized so that they are accessible in all parts of the world" (Rahtz 2005). Multilingualism is the new frontier in DH. Though we believe that glossaries and lists of equivalences can also help with the internationalization of the TEI, the vitality of multilingualism is a force both for the development of DH and the adoption of the TEI as standard, at least in countries where English is not understood as global or used as a language for scientific communication (Honna 2005).

The main channel of discussion in the TEI listserv is dominated by anglophones, while only a few other communities have their own channels, such as the French TEI listserv. This fact sometimes discourages Spanish speakers from raising their doubts, both because they are afraid of not expressing themselves correctly, and because the textual problems that they encounter 
are often difficult to contextualize not only from an anglophone perspective but also in a foreign language. Also, most of the news and updates on really useful materials, such as TEI Simple, are not disseminated in other languages and thus are not used in Spanish or Latin American projects. Unfortunately, the cost of membership and licenses, in the current context of the global economy, hinders many Global South researchers from becoming members of the TEI Consortium. Consequently, extremely useful resources such as TAPAS are not known and/or used by these communities. Also, one of the biggest drawbacks of teaching TEI in this context is the use of proprietary software in workshops. Although there are free XML editors, working with them is more challenging for novice Spanish students, requiring extra help for the markup activity and translation of tags. Proprietary licensing fees constrain the use of that software to short-term training opportunities. There is, as we have already mentioned, an absence of teaching materials in Spanish, such as websites, videos, presentations, and modules. While there are multiple web resources dealing with technical documentation in Spanish, such as tutorials on XML, XSLT, and XPath, they have not been created from a DH perspective, and thus they are inadequate for a humanities context. In addition, even though there are a lot of open access materials on the web on DH training and DSE in TEI in English, ${ }^{56}$ it is not enough for the Spanish-speaking community to translate them, since it is necessary to re-create the problems and adapt existing materials to their own needs and examples. There is a shortage of open source examples of real projects in Spanish..$^{57}$ As the TEI By Example team has noted, "being able to view the markup approaches of established scholars and projects in the field is an essential tool for TEI teaching which is currently not utilized" (Terras, Van den Branden and Vanhoutte 2009: 300). The few examples of encoded text in Spanish are the ones published by the Computergestützte literarische Gattungsstilistik. ${ }^{58}$ This situation has been addressed in Priani Saisó's blog post (2017), where a list of TEI encoding examples in Spanish is provided.

34 As a global trend, detailed documentation of editorial projects and other implementations of TEI is not a regular DH activity. This best practice should be highlighted by the TEI community and council as a benefit for the whole collective of TEI practitioners. Useful examples in Spanish include 
the contribution of the Red CHARTA $^{59}$ on how to encode a particular text typology (documents from the twelfth to nineteenth centuries), and the above mentioned Biblioteca del Pensamiento Novohispano.

Finally, many editing platforms and tools for DSE are not well known, either because they depend on websites or software entirely developed in English, German, or Dutch, or because the sites are not open access or require advanced technical knowledge to install the software. There are many different frameworks and platforms for this kind of tasks, such as TAPAS, TEI Boilerplate, Juxta, the Versioning Machine 5.0 (English), TextGrid and Ediarium (Germany), eLaborate (Holland), and Edictor (Brazil). ${ }^{60}$ However, for the Spanish-speaking community, the only current example we could highlight was the all-Spanish Virtual Research Environment (EVI-LINHD) ${ }^{61}$ developed at LINHD (UNED) in Spain. The EVI-LINHD environment ran from 2017 to 2020 creating very simple digital edition projects in an XML-TEI platform (González-Blanco et al. 2016, 2017b). It was developed as part of a research project that aimed at offering users an intuitive and user-friendly platform for encoding texts without seeing the TEI tags. Although EVI-LINHD was a good initiative, there is a clear need for more comprehensive and effective editing infrastructures for facilitating the use of the TEI in Spanish-speaking contexts. In a multilingual effort, ${ }^{62}$ the TEI Publisher (Exist DB Solutions) team has run a crowdsourcing project and started translations in different languages, including Spanish.

\section{The Need for Online Teaching Materials and a Case Study: the Text Technologies Hub and the Online Tutorial Introducción a la Text Encoding Initiative}

As we have tried to show in this article, in order to adopt the TEI, the academic community, individuals and institutions, need more resources available in their native language. In this last section, we would like to propose some strategies to address the challenges and issues mentioned above, particularly the translation of the TEI Guidelines and the creation of TEI educational materials in Spanish, and to outline an overall strategy for moving forward. 
Online tutorials devoted to text technologies and conceived for a broad array of learners-from beginners to advanced levels-are now commonplace (W3Schools, Lynda.com, CodeAcademy, among many others). Inspired by these kinds of resources, TEI By Example was developed several years ago, providing explanations, online tests, and exercises, although in English. This research team underscored in 2010 that:

If the digital humanities community wants to promote the TEI markup framework as a serious candidate for dedicated courses in the booming curricula on digital humanities ... then there is an urgent need for an on-line TEI course by example which is less generic than the two tutorials published on the TEI website (A Gentle Introduction to XML and TEI Lite: An introduction to Text Encoding for Interchange) and more general than the 29 guides to local practice on that site.

(Van den Branden, Terras, and Vanhoutte, 2010)

They also stressed the need for "an online TEI course which is ... more user friendly, comprehensive, and interactive than the online workshop materials which are currently presented as stand alone teaching materials" (Terras, Van Den Branden, and Vanhoutte 2009: 299). After all these years, while some of the issues that these authors emphasized remain the same, the importance of this kind of resource has been proved extensively and has significantly improved the overall situation for TEI users.

Recently, other interesting initiatives offering pedagogical materials have emerged, such as the above mentioned \#dariahTeach. This European project inside the consortium DARIAH has inaugurated a collection of courses in which we find three of them dealing with TEI: "Text Encoding and the TEI" by Susan Schreibman and Roman Bleier in English; French and Spanish versions of the same course, ${ }^{63}$ and "Digital Scholarly Editions: Manuscripts, Texts and TEI Encoding" by Elena Pierazzo and Marjorie Burghart. These three courses have explanatory videos, detailed contents, and exercises that can be considered as pioneers in the field of DH online teaching. In our case, for many years, we felt the need to gather in one single collaborative space the resources written in our language that would allow any Spanish-speaking researcher or student to work with the TEI and other text technologies. In 2018 we started a personal collaboration under the name of Text Technologies Hub or TTHub, a still-emerging project that aims to function as a collaborative open access platform of text technologies and materials in Spanish devoted to the 
Spanish community interested in the use of TEI as a standard for DSE and text technologies related to them. ${ }^{64}$ Our goal is to serve as a hub of open online materials, resources, news, software, and technologies that can potentially serve those interested in textual studies, digital editing, corpus construction, and digitization processes in Spanish. We think that many users of these resources, and especially textual scholars, need a site where they can find learning materials to uncover potential solutions in textual studies. As expected, our audience consists mostly of neophytes looking for introductory materials to the TEI, that is to say, those students and scholars with little or no prior experience in markup languages or textual data structures who would like to undertake a digital project or DSE.

40 So far, our attention has been devoted to text encoding with TEI, but we hope to open up the site to other methods and technologies. The platform, created with Wordpress, follows best practices for publishing materials using an open science approach, following, among others, the FAIR Data and the Scholarly Commons principles. ${ }^{65}$ We believe that when data is easily discoverable, accessible and reusable by others, knowledge can advance more quickly. In accordance with this set of principles, we offer all materials with an Attribution-Noncommercial-ShareAlike 4.0 International Creative Commons License ${ }^{66}$ Although this is a quite restrictive license, it must be considered that we publish very different kinds of materials from many different authors. We aim at protecting authorship while allowing scholars and students to build on each others' work in a fair way that benefits the entire community. In that sense, TTHub offers two ways of participating, either as a user who just consults the online materials, or through a registry that allows posting and working with the team. Finally, the materials we build, like Susanna Allés' lessons on TEI, are published as text and data with persistent identifiers: we generate a digital object identifier (DOI) archiving the materials in two open source repositories that work connected, GitHub and Zenodo. We consider that this is a best practice for making FAIR Open Educational Resources.

41 TTHub is organized in four main sections: Learn ("Aprende"), Participate ("Colabora"), Resources ("Recursos"), and News ("Noticias"). In the "Learn" section of the TTHub, we offer presentations from our workshops and talks, and a list which brings together curated resources-a list of tools as well as a Spanish bibliography in Zoter ${ }^{67}$ - that we consider useful for learning TEI and other text technologies. All these sections are open to collaboration and community feedback and give users the opportunity to participate by contributing information or resources that might interest the 
Spanish-speaking TEI community. Most important, in this first section, we currently offer a tutorial "Introducción a la Text Encoding Initiative," divided into seven lessons in Spanish devoted to TEI. ${ }^{68}$ These materials were developed by Allés-Torrent and are a version of the teaching materials inspired by the several seasons of the Experto Profesional en Humanidades Digitales created in January 2014 at the LINHD-UNED (currently the Master Universitario en Humanidades Digitales). It has circulated among more than 150 students thus far for more than five years with positive feedback.

42 Within this TEI tutorial that covers the first steps in a DSE, we aim to give a general understanding of TEI mechanisms from the true beginner's perspective, while we collaborate on distributing learning materials to the Spanish speaking community. We believe a resource such as this can facilitate the learning experience of scholars and students in a self-taught experience, as part of the materials of an academic syllabus, or even as the common ground for workshops and other training events.

43 The tutorial is divided into seven lessons that, as a whole, explain how to build a complete DSE with TEI: 1. Introduction, 2. Fundamentals of XML Languages, ${ }^{69}$ 3. General structure of a TEI document and General TEI Elements, ${ }^{70}$ 4. The TEI Guidelines, ${ }^{71}$ 5. Textual typologies, ${ }^{72}$ 6. Customization of schemas, ${ }^{73}$ and 7. Creation and use of the ODD.$^{74}$ These lessons are complemented by two other GitHub repositories, one containing exercises ${ }^{75}$ and another one showcasing examples ${ }^{76}$ of encodings in TEI created ad hoc by the team. Both repositories are open to collaboration, and we truly hope that these resources will be considered by the Spanish-speaking community to gather more samples.

44 In the Resources section, we also offer a list, downloadable as a CSV file ${ }^{77}$ with online encoding examples. As the community grows, this examples section should be enriched with documentation and real case encoding samples with Spanish texts. The reason behind this list is the fact that, although there are already lists of projects using TEI, sometimes-and especially for our students -is difficult to locate the TEI encoded files. Consequently, we have a quicker access and we learn from real case scenarios.

45 Finally, we would like to add that, in the "Participate" tab, we have opened up a section to collaboratively participate in a crowdsourced Spanish translation of the TEI Guidelines. The idea is to involve the Spanish-speaking community in the use of the TEI, not only through a tutorial 
or through curated resources and tools, but also through a personal experience in which English turns into Spanish. This crowdsourced Spanish translation, in which professors and students from Argentina, Spain, and Chile are already actively participating online and in different TEI workshops, is open to any interested person in the TEI who wishes to collaborate. Through it we hope not only to spread the word about the advantages of the TEI, but also to create a linguistic community of practice. This initiative will be carried out together with the above mentioned TEI Internationalization Working Group.

\section{Some Conclusions}

Teaching TEI using Spanish as a language for both written learning materials and written or oral communication in the different pedagogical contexts is a challenging experience. On the one hand, we face the specific physical characteristics of the different scenarios we have studied here-faceto-face and distance education, Foreign Language Classroom-each of which requires a different and specific strategic approach. On the other hand, we basically work within two linguistic levels since English has been very present in the primary materials we use or refer to, including the TEI tags ${ }^{78}$ the TEI Consortium website, the TEI Guidelines text, and scientific articles and books, even as we slowly try to break this barrier by developing our own materials.

47 Nevertheless, the slow process of creating and incorporating some translated but mostly new pedagogical materials adapted to the needs of our students in Spain and Latin America, and in the Foreign Language Classrooms in the United States, was, in fact, a turning point: it helped students see how adaptable a standard language, such as the TEI, could be, and how a markup language can enhance scholarship in the digital age. Moreover, having tutorials, examples, and documentation in our native language proved that the English in the metadata-in elements, attributes, or values - was not an insurmountable obstacle to surpass in order to work successfully in TEI, for instance, in the making of a DSE.

48 A situated learning process based on Spanish literary texts and the creation of pedagogical materials in Spanish, such as our TTHub initiative, may facilitate the adoption of the TEI by the Spanish-speaking community around the world, and may help in other contexts, like the Foreign 
Language Classroom (where Spanish is the foreign language). Therefore, we believe that this type of multilingual resource may help not only to extend the use of a standard like the TEI, but also to consolidate DH as a global academic community around the world.

\section{BIBLIOGRAPHY}

Allés Torrent, Susanna. 2015. “Edición digital y algunas tecnologías aliadas.” Ínsula, 812: 18-21. doi:10.7916/ D89S1QFN.

- - . 2017. "Tiempos hay de acometer y tiempo de retirar: literatura áurea y edición digital." Studia Aurea. Revista de Literatura Española y Teoría Literaria del Renacimiento y Siglo de Oro 11: 13-30. doi:10.5565/rev/ studiaaurea.261.

Baldwin, Sandy. 2013. "The Category of the Literary and the Essence of Digital Humanities, or Some Notes on the Context of My Essay for Digital Humanities Quarterly." Digital Humanities Quarterly 7 (1). http:// www.digitalhumanities.org/dhq/vol/7/1/000155/000155.html.

Battershill, Claire and Shawna Ross. 2017. Using Digital Humanities in the Classroom. A Practical Introduction for Teachers, Lecturers, and Students. London: Bloomsbury.

Bia, Alejandro, and Andrés Pedreño. 2001. “The Miguel de Cervantes Digital Library: the Hispanic Voice on the Web." Literary and Linguistic Computing 16 (2), 161-177 doi:https://doi.org/10.1093/llc/16.2.161.

Burnard, Lou. 2001. "On the hermeneutic implications of text encoding." In New Media and the Humanities: Research and Applications, edited by Domenico Fiormonte and Jonathan Usher, 31-38. Oxford: Humanities Computing Unit. http://users.ox.ac.uk/ lou/wip/herman.htm.

Cummings, James. 2017. “The Text Encoding Initiative and the Study of Literature.” In A Companion to Digital Literary Studies, edited by Ray Siemens and Susan Schreibman, 451-76. Oxford: Blackwell.

Dee, Stella. 2014. "Learning the TEI in a Digital Environment." Journal of the Text Encoding Initiative 7 (November). doi:10.4000/jtei.968.

Dee, Stella, Maryam Foradi, and Filip Šarić. 2016. "Learning by Doing: Learning to Implement the TEI Guidelines Through Digital Classics Publication." In Digital Classics Outside the Echo-Chamber: Teaching, Knowledge Exchange \& Public Engagement, edited by Gabriel Bodard and Matteo Romanello, 15-32. London: Ubiquity Press. doi:10.5334/bat.b. 
Del Rio Riande, Gimena. 2015a. "Humanidades Digitales. Mito, actualidad y condiciones de posibilidad en España y América Latina." ArtyHum 1: 7-19 . November. https://www.artyhum.com/descargas/ monograficos/MONOGR\%C3\%81FICO\%20HD.pdf.

- - . 2015b. “¿De qué hablamos cuando hablamos de Humanidades Digitales? .” In Actas I Jornadas de Humanidades Digitales de la AAHD, 50-62. Buenos Aires: Editorial de la Facultad de Filosofía y Letras. https://www.aacademica.org/jornadasaahd/3.pdf.

- - . 2016a. "De todo lo visible y lo invisible o volver a pensar la investigación en humanidades digitales." Signa: Revista de la Asociación Española de Semiótica (UNED) 25: 95-108. http://revistas.uned.es/index.php/ signa/article/view/16943.

-_- "Ada en la encrucijada de las Humanidades Digitales." Luthor 29 (August). http:// www.revistaluthor.com.ar/spip.php?article149.

Del Rio Riande, Gimena and Carina Zubillaga. 2015. “Un proyecto de edición digital académica en Argentina. Diálogo Medieval." In Actas I Jornadas de Humanidades Digitales de la AAHD, 100-114. Buenos Aires: Editorial de la Facultad de Filosofía y Letras.

Driscoll, Matthew James and Elena Pierazzo (eds.). 2016. Digital Scholarly Editing: Theories and Practices. Open Book Publishers. doi:10.11647/OBP.0095.

Faulhaber, Charles B. 1994. “La Text Encoding Initiative y su aplicación a la codificación textual y explotación.” Actas del Congreso de la Lengua Española: Sevilla, 7 al 10 octubre, 1992, 331-340. Madrid: Instituto Cervantes.

Fiormonte, Domenico. 2014. "Digital Humanities from a global perspective." Laboratorio dell'ISPF 9. http:// www.ispf-lab.cnr.it/2014_203.pdf. doi:10.12862/ispf14L203.

Fiormonte, Domenico and Gimena del Rio Riande. 2017. "Por unas Humanidades Digitales globales." Infolet. Cultura e critica del media digitali 10. https://infolet.it/2017/10/09/humanidades-digitales-globales/.

Fradejas Rueda, José Manuel. 2009-2010. “La codificación XML/TEI de textos medievales.” Memorabilia, 12: 219-247.

Galina, Isabel. 2013. "Is There Anybody Out There? Building a global Digital Humanities community." Blog colectivo de la Red de Humanidades Digitales de México, July 19, 2013, http://humanidadesdigitales.net/ blog/2013/07/19/is-there-anybody-out-there-building-a-global-digital-humanities-community/.

Gold, Matthew K. (ed.). 2012. Debates in the Digital Humanities. Minneapolis, MN: University of Minnesota Press. doi:10.5749/minnesota/9780816677948.001.000.

Gold, Matthew K., and Lauren F. Klein (eds.). 2016. Debates in the Digital Humanities. Minneapolis, MN: University of Minnesota Press.

González-Blanco, Elena, Clara Martínez Cantón, Gimena del Rio Riande, and María Dolores Martos. 2014. "La codificación informática del sistema poético medieval castellano, problemas y propuestas en la elaboración de un repertorio métrico digital: ReMetCa." In Visibilidad y divulgación de la investigación 
desde las Humanidades Digitales. Experiencias y proyectos, edited by Alvaro Baraibar, 172-185. Pamplona: Servicio de Publicaciones de la Universidad de Navarra. http://www.unav.edu/publicacion/bibliotecaaurea-digital/BIADIG-22.

González Blanco García, Elena, Antonio Robles-Gómez, Salvador Ros, Gimena Del Rio Riande, Roberto Hernández, Miguel Urizar, Clara Martínez Cantón, Rafael Pastor, and Jesús Cano. 2016. “TEIScribe: A graphic tool for composing and testing TEI documents in the context of the EVI-LINHD environment." In TEI Conference and Members' Meeting 2016. Book of Abstracts, edited by Claudia Resch, Vanessa Hannesschläger, and Tania Wissik, -. Vienna: Druck- und Handelsgesellschaft mbH.

González-Blanco, Elena, Gimena del Rio, and Clara Martínez. 2017a. "Using e-learning systems for DH teaching: the Spanish Humanidades Digitales case study at LINHD.” Abstract of paper presented at Digital Humanities 2017. Montréal: McGill University - Université de Montréal. https://dh2017.adho.org/ abstracts/429/429.pdf.

González-Blanco, Elena, Clara Martínez Cantón, Gimena del Rio Riande, Salvador Ros, Rafael Pastor, Antonio Robles-Gómez, Agustín Caminero, María Luisa Díez Platas, Álvaro del Olmo, and Miguel Urízar. $2017 b$. "EVI-LINHD, a virtual research environment for the Spanish-speaking community." Digital Scholarship in the Humanities 32(2). doi:10.1093/llc/fqx025.

Hirsch, Brett D., ed. 2012. Digital Humanities Pedagogy. Practices, Principles and Politics. Cambridge: Open Book Publishers. doi:10.11647/OBP.0024.

Honna, Nobuyuki. 2005. "English as a Multilingual Language in Asia and Intercultural Literacy." Intercultural Communication Studies XIV:2. https://web.uri.edu/iaics/files/06-Nobuyuki-Honna.pdf.

Irizarry, Estelle. 1997. Informática y literatura. Análisis de textos hispánicos. Madrid: Anthropos.

Isasi Martínez, Carmen, Leyre Martín Aizpuru, Santiago Pérez Isasi, Elena Pierazzo, and Paul Spence. 2020. Edición digital de documentos antiguos: marcación XML_TEI basada en los criterios CHARTA. Sevila: EUS.

Lave, Jean, and Etienne Wenger. 1991. Situated Learning: Legitimate Peripheral Participation. Cambridge: Cambridge University Press.

Lucía Megías, José Manuel. 2008. “Las relaciones entre la bibliografía textual y la informática humanística: El incunable del hipertexto." Tipolologia. Rivista Internazionale di Studi Filologici e Linguistici sui testi a stampa 1: 119-138.

Marcos Marín, Francisco A. 1986. “Metodología informática para la edición de textos.” Incipit 6: -.

--_. 1994. Informática y Humanidades. Madrid: Gredos.

Mahony, Simon, and Elena Pierazzo. 2012. “Teaching Skills or Teaching Methodology?” In Digital Humanities Pedagogy: Practices, Principles and Politics, edited by Brett D. Hirsch, 215-6. Cambridge: Open Book Publishers. doi:10.11647/OBP.0024. 
McCarl, Clayton. 2018. "Multiple-Layered Encoding as an Editorial and Pedagogical Strategy in Colonial Latin American Studies." Bulletin for Spanish and Portuguese Historical Studies 48 (1): 40-52. https:// digitalcommons.asphs.net/bsphs/vol43/iss1/3/.

Morrás, Maria. 2003. “Informática y crítica textual: realidades y deseos.” In Literatura hipertextual y teoría literaria, edited by María José Vega, 225-41. Madrid: Mare Nostrum Communicación.

Nagasaki, Kiyonori. 2020. “Evasion of breathing tax: editing TEI with VSCode.” In digitalnagasaki\#\#\#. February 2nd, 2020. https://digitalnagasaki.hatenablog.com/entry/2020/02/15/045531.

O’Donnell, Daniel P. 2012. “In a rich man's world: Global DH?," dpod blog. The first draft of my research, teaching and reading, November 2, 2012, http://dpod.kakelbont.ca/2012/11/02/in-a-rich-mans-world-global-dh/.

O’Donnell, Daniel P., Katherine L. Walter, Alex Gil, and Neil Fraistat. 2016a. “Only Connect: The Globalization of the Digital Humanities." In A New Companion to Digital Humanities, 2nd Edition, edited by Susan Schreibman, Ray Siemens, and John Unsworth, 493-510. Chichester: Wiley-Blackwell.

O’Donnell, Daniel P., Barbara Bordalejo, Padmini Murray Ray, Gimena del Rio, and Elena González-Blanco. 2016b. "Boundary Land: Diversity as a defining feature of the Digital Humanities." In Digital Humanities 2016. Conference Abstracts: 76-82. Kraków: Jagiellonian University \& Pedagogical University. http:// dh2016.adho.org/abstracts/406.

Priani Saisó, Ernesto. 2007. "Revista Digital Universitaria: A Workshop of Digital Editing at the Universidad Nacional Autónoma de México.” Digital Humanities Quarterly 1 (2). http://digitalhumanities.org/dhq/ $\mathrm{vol} / 1 / 2 / 000014 / 000014 . h \mathrm{tml}$.

-_-. 2017. "Documentos con marcado TEI en español." ernestopriani.com, August 12. https:// ernestopriani.com/blog/documentos-con-marcado-tei-en-espanol/.

Priani Saisó, Ernesto. 2019. “Codificación y buenas prácticas. Crítica a la delimitación de las humanidades digitales en América Latina." Relaciones. Estudios de historia y sociedad XL(158), 129-144. doi:10.24901/ rehs.v40i158.343.

Rahtz, Sebastian. 2005. “TEI Internationalization” (Presentation). Available at: https://tei-c.org/Vault/ Talks/2005/Wuerzburg/i18n.pdf.

Revenga, Nàdia. 2014. "La edición crítica digital de textos teatrales. La Estrella de Sevilla como ejemplo." Anuario de Lope de Vega. Texto, literatura, cultura 20: 99-121. doi:10.5565/rev/anuariolopedevega.85.

Rodríguez Temperley, María M. 2008. "La Edad Media en las tierras del Plata: a propósito del medievalismo en la Argentina." Revista de Poética Medieval 21: 221-293.

Rojas Castro, Antonio. 2017. "La edición crítica digital y la codificación TEI. Preliminares para una nueva edición de las Soledades de Luis de Góngora." Revista de Humanidades Digitales 1: 4-19. doi:10.5944/ rhd.vol.1.2017.16379. 
Schöch, Christof. 2020. “Can Atom replace oXygen?” The Dragonfly's Gaze. Computational analysis of literary texts. March 28th, 2020. https://dragonfly.hypotheses.org/1127.

Spence, Paul. 2014. “Edición académica en la era digital: modelos, difusión y proceso de investigación.” Anuario Lope de Vega: Texto, literatura, cultura 20: 47-83. doi:10.5565/rev/anuariolopedevega.74.

Spence, Paul, and Elena González Blanco. 2014. "A historical perspective on the digital humanities in Spain.” The Status Quo of Digital Humanities in Spain, H-Soz-Kult, http://www.hsozkult.de/debate/id/ diskussionen-2449.

Terras, Melissa, Ron Van Den Branden, and Edward Vanhoutte. 2009. "Teaching TEI: The Need for TEI by Example." Literary and Linguistic Computing 24 (3): 297-306. doi:10.1093/llc/fqp018.

Van den Branden, Ron, Melissa Terras, and Edward Vanhoutte. 2010. TEI by Example. Last updated July 9, 2010. http://www.teibyexample.org/.

\section{NOTES}

1 TEI will be used both to address to the consortium and the markup language.

2 Such is the case of several communities like Japan, India or South Africa, that use English as a koiné language inside academia. This is not the case in Latin America and other Spanish Speaking regions where English is not the language for scientific communication.

3 https://tei2018.dhii.asia/.

4 Most of the themes and topics in this section are studied more extensively by del Rio Riande in "Humanidades Digitales: Life on the other Side," keynote presentation at TEI conference and members meeting, Victoria, British Columbia, Canada, November 11 - 15, 2017.

5 Red de Humanidades Digitales (RedHD), http://www.humanidadesdigitales.net/.

6 Associação das Humanidades Digitais (AHDig), https://ahdig.hypotheses.org/.

7 Humanidades Digitales Hispánicas. Sociedad (HDH), https:// humanidadesdigitaleshispanicas.es/.

8 Associació d'Humanitats Digitals Catalanes (AHDCat), http://ahdcat.org/.

9 Asociación Argentina de Humanidades Digitales (AAHD), http://aahd.net.ar/.

10 http://buenosaires2013.thatcamp.org/.

11 Red Colombiana de Humanidades Digitales, http://www.rehdi.co/. 
12 Asociación Uruguaya de Humanidades Digitales (HDU), https://www.facebook.com/ DHUruguay/. This institutional growth of associations is also a European trend, that in the last years has also seen the creation of the Associazione di Informatica Umanistica (AIUCD), http:// www.aiucd.it/, in Italy, the Digital Humanities im deutschsprachigen raum (DHD), https://dighum.de/, in Germany, and Humanistica-Association francophone des humanités numériques/ digitales, http://www.humanisti.ca/, smartly created as a Francophone association in which it is the linguistic liaison that prevails, rather than the geographic element. All of them count on listserv as their main channel of communication to spread the news.

13 A mailing list that aims at bringing together dh'ers in Latin America: latamhd@lists.humanidadesdigitales.net (https://www.latamhd.net/).

14 Máster Universitario en Patrimonio Textual y Humanidades Digitales: https://diarium.usal.es/ masteriemyr/.

15 MA in Humanities and Digital Heritage: https://www.uab.cat/web/estudiar/l-oferta-demasters-oficials/informacio-general/humanitats-i-patrimoni-digitals-1096480139517.html? param1=1345803179474.

16 MA in Digital Humanities: https://www.ub.edu/portal/web/informacio-mitjans-audiovisuals/ masters-universitaris/-/ensenyament/detallEnsenyament/5900191/1.

17 Máster Universitario Historia y Humanidades Digitales: https://www.upo.es/postgrado/ Master-Oficial-Historia-y-Humanidades-Digitales.

18 https://www.ucm.es/master-letrasdigitales/.

19 http://linhd.uned.es/.

20 For more information, see: http://linhd.uned.es/p/dh-master-humanidades-digitales-2019/.

21 https://www.unir.net/humanidades/master-humanidades-digitales/549203796794/.

22 https://tinyurl.com/ycm9nsm3.

23 https://www.elclaustro.edu.mx/maestr\%C3\%ADas/maestria-en-comunicacion-yhumanidades-digitales/.

24 http://www.humanidadesdigitales.net/seminario-hd/.

25 http://hdlab.space/.

26 See a full list of courses and workshops on his personal website: http://alexbia.edu.umh.es/ academia/docencia/. 
27 http://gmlc.imf.csic.es/2013/Workshop/index.php.

28 A very complete approach in Priani Saisó (2019).

29 http://buenosaires2013.thatcamp.org/.

30 “Introducción a la Edición Digital Académica," by Gimena del Rio Riande, Clara Martínez Cantón, and Elena González Blanco. See: https://www.aacademica.org/jornadasaahd/95.

31 This workshop was taught by the authors as part of the activities offered in Buenos Aires after the Third International Conference of the AAHD, held in the city of Rosario, Argentina, in 2018: https://tthub.io/aprende/taller-hackathon-buenos-aires/.

32 See the first DH four-month course taught by Gimena del Rio Riande at Facultad de Filosofía y Letras in 2015: https://tinyurl.com/ycsbjyzu and others as part of the Medieval Hispanic Literature classes (2017).

33 An online two-month course taught by Gimena del Rio and Natalia Corbellini (2016) in an Argentinian university. See: https://tinyurl.com/y8rb2reu.

34 https://tinyurl.com/y8eryh7d.

35 In 2017, Gimena del Rio Riande and Elena González Blanco taught a workshop on the use of TEI for DSE, as well as two other workshops devoted to the Digital Editing inside and outside Academy, with special emphasis on the use of TEI, in 2018 during the Feria del Libro de la Habana: http://www.saavedra15-conicet.gov.ar/iibicrit-entrevista-a-la-dra-del-rio-riande-en-laxxvii-feria-del-libro-de-la-habana/.

36 The Catalogue of Digital Editions, by Greta Franzini, https://dig-ed-cat.acdh.oeaw.ac.at/, and the Catalogue of Digital Scholarly Editions, by Patrick Sahle, http://www.digitale-edition.de/.

37 https://miocid.wlu.edu/?v=nor.

38 http://www.kb.dk/permalink/2006/poma/info/en/frontpage.htm and http:// codicemendoza.inah.gob.mx/inicio.php.

39 http://www.cartas-de-ultramar.net/, http://www.gep.group.shef.ac.uk/, http:// goytisolo.unibe.ch/, http://jlromero.com.ar/.

40 Documentation can be found at the project's site: http://www.bdpn.unam.mx/documentation. See also a list of projects from Spain and Latin America that use the TEI for encoding and publishing in Priani Saisó 2017.

41 https://digitalpedagogy.mla.hcommons.org/. 
42 http://www.digitalhumanities.org/dhq/vol/11/3/index.html.

43 For more information, see: http://www.tei-c.org/Activities/SIG/Education/.

44 The project is part of DARIAH (Digital Research Infrastructure for the Arts and the Humanities) and available at https://teach.dariah.eu/. This initiative has recently created a Registry of DH courses https://registries.clarin-dariah.eu/courses/, but, as expected, it collects mostly European initiatives.

45 It is sometimes forgotten that most Latin American countries do not integrate the higher positions in the English Proficiency Index (EPI): https://www.ef.com.es/epi/.

46 Paige Morgan has collected a list of skills in libraries: "Requested skills and expertise, DH/DS front facing library positions, 2010-2018," https://public.tableau.com/profile/paige.morgan\#!/ vizhome/RequestedskillsexpertiseDHDSlibrarypositions2010-2018/ RequestedskillsandexpertiseDHDSfrontfacinglibrarypositions2010-2018.

47 For some examples, see notes 30, 31, 32, 34 and 35. In 2019, Gimena del Rio started directing the project "Reis Trobadors: reconstrucción filológico-musicológica de la lírica medieval románica con herramientas digitales" (Filo:CyT) in which students learn to use the TEI and publish medieval Castilian and Galician-Portuguese poetry with minimal technologies. See: http://hdlab.space/ Poesia-Medieval/ (site under construction by the students with HD CAICYT Lab members' supervision). In 2020, del Rio and Raffaele Viglianti are starting the course "Digital Publishing with Minimal Computing: digital humanities at a global scale," which is part of the Global Classrooms Program based at the University of Maryland (USA) and the Universidad del Salvador (Argentina). The course, which will run for three years, uses minimal publishing technologies based on TEI encoding.

48 In 2019, we taught the online course "Explorar las Humanidades Digitales" in Argentina: http:// citep.rec.uba.ar/explorar-las-humanidades-digitales-2/. Although the two-month course was not mainly focused on TEI, in the last section devoted to semantic annotation with Recogito (Pelagios Network) we presented a theoretical approach to TEI encoding.

49 See notes 19, 20 and 33.

50 At an undergraduate level, some of our experiences teaching TEI and guiding our students towards an editorial project are: Mini Lazarillo: edición mínima del Lazarillo de Tormes, 2016, https://minilazarillo.github.io/ (Columbia University), and Lorca descubriendo las Américas, 2017, 
https://susannalles.github.io/teaching/SPA322/Web_Lorca/, a project that took advantage of a collection from the Richter Library at the University of Miami, http://merrick.library.miami.edu/ cubanHeritage/chc5324/.

51 http://sites.utexas.edu/llilasbensonds/projects/relaciones-geograficas/.

52 https://uh.edu/news-events/stories/2019/august-2019/07312019-us-latino-digitalhumanities-program.php.

53 It must be highlighted that some capstone publications on DH and Pedagogy, such as the Debates in Digital Humanities (Gold 2012; Gold and Klein 2016) or Digital Humanities Pedagogy (Hirsh 2012) do not explore this problem, nor do Spanish case studies appear in international publications on DSE (Driscroll and Pierazzo 2016).

54 For a list of translations, see http://www.tei-c.org/Tools/I18N/.

55 For information on the first TEI internationalization efforts, see: https://tei-c.org/tools/ i18n/tei-internationalization-proposal/. In October 2019 a group of TEI members-Hugh Cayless, Martina Scholger, Luis Meneses, Gimena del Rio Riande, Helena Bermúdez Sabel, and Kiyonori Nagasaki- met at the Triangle Scholarly Communication Institute hosted by Duke University Libraries to discuss the topic of "Communicating the TEI to a Multilingual User Community." This second working group is part of the conversations at that event. See: https:// trianglesci.org/2019/07/17/communicating-the-tei-to-a-multilingual-user-community/.

56 This is the case with, for instance, DiXit materials, http://dixit.uni-koeln.de/programme/ materials/.

57 https://wiki.tei-c.org/index.php/Samples_of_TEI_texts.

58 Collection of 19th Century Spanish-American Novels (1880-1916), edited by Ulrike Henny-Krahmer (which contains 24 novels), or the Corpus of Spanish Novels from 1880-1940, edited by José Calvo Tello (with 39 novels) (https://github.com/cligs/textbox).

59 https://www.redcharta.es/. The team released the materials under the publication Isasi Martínez et al. (2020).

60 Projects are available at: http://tapasproject.org/, http://dcl.ils.indiana.edu/teibp/ index.html, http://juxtacommons.org/, http://v-machine.org/, https://textgrid.de, http:// www.bbaw.de/telota/software/ediarum, https://www.elaborate.huygens.knaw.nl/login, and https://edictor.net/. 
61 http://evi.linhd.uned.es/.

62 https://crowdin.com/project/tei-publisher/invite/public?

show_welcome\&d=13c9b3c4d6ad86964f49920c6929ad491158629.

63 https://teach.dariah.eu/course/view.php?id=23.

64 This project, available at http://tthub.io, is coordinated by the authors with the collaboration of the PhD student Gabriel Calarco (University of Buenos Aires). So far, it is undertaken with no funding or external support.

65 The FAIR Data Principles are a set of guiding principles in order to make data findable, accessible, interoperable and reusable. FORCE11 houses the 15 FAIR Data Principles: https:// www.force11.org/group/fairgroup/fairprinciples. The Scholarly Commons principles are a set of best practices, interfaces and standards that aim at governing the multi-directional flow of scholarly objects through all phases of the research process. More about these principles: https:// www.force11.org/scholarly-commons/about.

66 https://creativecommons.org/licenses/by-nc-sa/4.0/.

67 https://www.zotero.org/groups/2285352/tei_en_espaol.

68 They are available at https://tthub.io/aprende/introduccion-a-tei/. A flat version in PDF of the single lessons can also be downloaded under a Creative Commons license and accessed through our GitHub and Zenodo repositories: https://github.com/tthub-repo/lecciones and https:// zenodo.org/communities/tei_espanol/.

$69 \mathrm{https} / / / \mathrm{tthub} . \mathrm{io} / \mathrm{aprende/l2-xml/}$.

70 https://tthub.io/aprende/l3-basicos-tei/.

71 https://tthub.io/aprende/l4-guias/.

72 https://tthub.io/aprende/l5-tipologias/.

73 https://tthub.io/aprende/l6-esquemas/.

74 https://tthub.io/aprende/l7-odd/.

75 https://github.com/tthub-repo/ejercicios.

76 https://github.com/tthub-repo/ejemplos.

77 https://tthub.io/recursos/ejemplos-tei/. 
78 The fact that an editor like Oxygen helps learners significantly in this process must be highlighted, as it offers a translation of the tags while using them in the encoding activity. However, it should be highlighted that in recent years, different open source editors like JEdit or Atom, and also VS Code, have made significant efforts to incorporate plugins to support TEI encoding (Nagasaki 2020, Schöch 2020). Some of them are currently exploring options for offering the tag content translated into other languages.

\section{AUTHORS}

\section{SUSANNA ALLÉS-TORRENT}

Susanna Allés-Torrent is Assistant Professor in the Department of Modern Languages and Literatures at the University of Miami, where she teaches Digital Humanities, Medieval and Early Modern Romance Literature, and Spanish culture.

\section{GIMENA DEL RIO RIANDE}

Gimena del Rio Riande is Adjunct Researcher at the Instituto de Investigaciones Bibliográficas y Crítica Textual (IIBICRIT-CONICET, Argentina) and the Director of Humanidades CAICYT Lab at the Centro Argentino de Información en Ciencia y Tecnología (CAICYT-CONICET). She is also External Professor at Universidad de Buenos Aires (UBA) and co-director of the Digital Humanities Master at LINHD-UNED (Spain). 